Original Research

\title{
Pengaruh Kualitas Pelayanan dan Motivasi Kerja terhadap Kinerja Melalui Kepuasan Kerja Pegawai Pada Kantor BPPRD Palangka Raya
}

\author{
Reiny Irianti Poetri ${ }^{1,}$, Bambang Mantikei ${ }^{2}$, Thresia Kristiana ${ }^{2}$ \\ ${ }^{1}$ Badan Pengelola Pajak dan Retribusi Daerah (BPPRD) Kota Palangka Raya \\ 2 Program Studi Magister Manajemen, Program Pascasarjana Universitas Palangka Raya, Kampus UNPAR Tunjung Nyaho, \\ J. Yos Sudarso Palangka Raya, Indonesia 73111 \\ * Korespondensi: Reiny Irianti Poetri (Email: reiny.poetri89@gmail.com)
}

\begin{abstract}
Government agencies' service standards have been established based on MENPAN Decree No. 25/2004. Therefore it is necessary to review the giving of work motivation, so that job satisfaction and performance can be improved again. The purpose of this research is to measure and analyze the direct and indirect effects of service quality, work motivation, on job satisfaction and performance and to measure and analyze the direct influence and indirect effect between job satisfactions on employee performance. The sample of the study consisted of 200 people taxpayers service staff Palangka Raya BPPRD Office. Research data in the form of primary and secondary data obtained through observation and questionnaires. Data were analyzed using path analysis, while the job satisfaction variable was an intervening variable and performance was the dependent variable (the dependent variable). From the results of path analysis where the direct effect between service quality on job satisfaction and on performance has a significant effect, and work motivation on job satisfaction is not significant. While the indirect effect (indirect effects) quality of service on performance through job satisfaction with a coefficient of 0.115 is greater than work motivation on performance through job satisfaction by 0.030 , meaning that work motivation on performance through job satisfaction has a non-significant effect.
\end{abstract}

\section{Keywords}

Service quality, motivation, job satisfaction, performance, BPPRD

\section{PENDAhuluaN}

Pemerintah adalah sebuah institusi yang prinsip operasioalnya adalah melayani masyarakat (public servant) dalam berbagai aspek kepentingan kehidupan sosial. Sedangkan instansi pemerintah adalah suatu organisasi atau lembaga (wadah) yang memusatkan suatu pelayanan terhadap masyarakat. Pentingnya peranan pemerintah ini karena tidak ada institusi lain yang bersedia dan mampu melaksanakan fungsi sosial tanpa berharap mendapatkan keuntungan (private benefit). Hal ini wajar dan sesuai dengan prinsip demokrasi ekonomi, dimana fungsi pemerintah selain sebagai inovator (yang memulai) juga sebagai motivator (yang mendorong) dan bahkan fasilisator (yang memfasilitasi pelayanan publik baik dalam arti fisik maupun administrasi dalam birokrasi).

Disisi lain, salah satu sumber pendapatan daerah untuk membiayai pembangunan adalah pajak, dimana pemerintah sebagai inovator (yang memulai) juga sebagai motivator (yang mendorong) dan bahkan fasilisator (yang memfasilitasi pelayanan publik), sangat tertantang untuk meningkatkan kesadaran masyarakat dalam membayar pajak. Banyak cara pemerintah untuk meningkatkan motivasi masyarakat untuk membayar pajak. Salah satunya adalah mengaitkan dengan balik nama, yang merupakan kerjasama dengan instransi pemerintah lainnya. Artinya, jika masyarakat ingin melakukan balik nama, maka ditetapkan bahwa masyarakat tersebut harus melunasi pajak pada bulan berjalan, setelah itu baru mengajukan bali nama.

Terlepas dari kebijakan pemerintah dengan mengaitkan instrumen lunas pajak pada tahun berjalan, maka kesadaran masyarakat dalam membayar pajak juga sangat tergantung pada kualitas pelayanan yang diselenggarakan oleh pegawai. Oleh karena itu, untuk dapat meningkatkan kualitas pelayanan para pegawai, maka pemerintah harus memberikan motivasi kerja bagi pegawai, jika pegawai merasakan bahwa motivasi kerja mereka cukup tinggi, maka kinerja merekapun dapat ditingkatkan. Artinya kualitas pelayanan yang diberikan oleh pegawai sangat 
tergantung pada kepuasan kerja mereka dan motivasi kerja yang akhirnya adanya peningkatan kinerja. Memang motivasi kerja yang tinggi biasanya datang sendiri dari dalam pegawai, namun semua itu tergantung pada orangnya (manusianya)

Terdapat lima unsur konsep kualitas pelayanan sebagaimana diungkapkan oleh Kotler (2018), yaitu: a) berwujud (tangible), yaitu aspek fisik dari sebuah pelayanan dan memasukan penampilan fasilitas fisik, peralatan, personel, dan materi komunikasi, karena pelayanan sendiri sifatnya tidak berwujud, konsumen sering kali menilai kualitas pelayanan dari hal berwujud yang terkait dengan pelayanan; b) kehandalan (reliability) dalam pelayanan yang didefinisikan secara berbeda dan kehandalan dalam produk. Dalam jasa, kehandalan berhubungan dengan kemampuan untuk melakukan pelayanan yang dijanjikan secara terpercaya dan akurat; c) daya respon (responsiveness), berupa keinginan provider jasa untuk membantu konsumen maupun memberikan pelayanan yang tanggap dan cepat; d) jaminan (assurance) yang berhubungan dengan pengetahuan dan kebaikan dari pekerja dan kemampuan mereka untuk menyampaikan kepercayaan dan keyakinan; e) empati (empathy) berupa kemampuan untuk menunjukkan perhatian secara perorangan kepada konsumen.

Standar pelayanan dan prinsip pelayanan tersebut diterjemahkan kedalam 14 unsur yang relevan, valid dan reliabel sebagai unsur minimal yang harus ada untuk pengukuran indeks kepuasan masyarakat. Berdasarkan Keputusan MENPAN Nomor 25 Tahun 2004 unsur-unsur tersebut adalah sebagai berikut: 1) prosedur pelayanan, yaitu kemudahan tahapan pelayanan yang diberikan kepada masyarakat dilihat dari sisi kesederhanaan alur pelayanan; 2) persyaratan pelayanan, yaitu persyaratan teknis dan administratif yang diperlukan untuk mendapatkan pelayanan sesuai dengan jenis pelayanannya; 3) pejelasan petugas pelayanan, yaitu kesungguhan petugas dalam memberikan pelayanan (nama, jabatan serta kewenangan dan tanggung jawabnya); 4) disiplin petugas pelayanan, yaitu kesungguhan petugas dalam memberikan pelayanan terutama konsistensi waktu kerja sesuai ketentuan yang berlaku; 5) tanggung jawab petugas pelayanan, yaitu kejelasan wewenang dan tanggung jawab petugas dalam penyelenggaraan dan penyelesaian pelayanan; 6) kemampuan petugas pelayanan, yaitu tingkat keahlian dan keterampilan yang dimiliki petugas dalam memberikan/ menyelesaikan pelayanan kepada masyarakat; 7) kecepatan pelayanan, yaitu target waktu pelayanan dapat diselesaikan dalam waktu yang telah ditentukan oleh unit penyelenggara pelayanan; 8) keadilan mendapatkan pelayanan, yaitu pelaksanaan pelayanan dengan tidak membedakan golongan/status masyarakat yang dilayani; 9) kesopanan dan keramahan petugas, yaitu sikap dan perilaku petugas dalam memberikan kepada masyarakat secara sopan dan ramah serta saling menghargai dan menghormati; 10) kewajaran biaya pelayanan, yaitu keterjangkauan masyarakat terhadap besarnya biaya yang ditetapkan oleh unit pelayanan; 11) kepastian biaya pelayanan, yaitu kesesuaian antara biaya yang dibayarkan dengan biaya yang telah ditetapkan; 12) kepastian jadwal pelayanan, yaitu pelaksanaan waktu pelayanan, sesuai dengan ketentuan yang telah ditetapkan; 13) kenyamanan lingkungan, yaitu kondisi sarana dan prasarana pelayanan yang bersih, rapi, dan teratur sehingga dapat memberikan rasa nyaman kepada penerima pelayanan; 14) keamanan pelayanan, yaitu terjaminnya tingkat keamanan lingkungan unit penyelenggara pelayanan ataupun sarana yang digunakan, sehingga masyarakat merasa tenang untuk mendapatkan pelayanan terhadap resiko-resiko yang diakibatkan dari pelaksanaan pelayanan.

Jika semua itu dilaksanakan dengan baik oleh para pegawai dalam memberikan pelayanan, maka ada persepsi masyarakat tentang perbaikan kinerja pegawai. Oleh karena itu, perlu meningkatkan kepuasan kerja para pegawai yang salah satunya adalah dengan memberikan motivasi kerja sehingga kinerja pegawai dapat ditingkatkan. Robbins (2016) mendefinisikan kepuasan kerja sebagai suatu sikap umum seorang individu terhadap pekerjaannya dimana dalam pekerjaan tersebut seseorang dituntut untuk berinteraksi dengan rekan sekerja dan atasan, mengikuti aturan dan kebijaksanaan organisasi, memenuhi standar kinerja. Dalam melaksanakan pekerjaannya dipengaruhi oleh faktor yang merupakan kebutuhan, salah satunya adalah motivasi kerja. Menurut Hasibuan (2016), manusia selain merupakan unsur pelaksana dari pada kebijakan-kebijakan dalam organisasi, mereka juga merupakan mahluk yang mempunyai pikiran, perasaan, kebutuhan, serta harapan-harapan tertentu. Hal ini sangat memerlukan perbatian tersendiri karena faktorfaktor tersebut akan mempengaruhi kinerja, dedikasi, dan kepuasan kerja (Hasibuan, 2016).

Usaha yang dilakukan manusia melalui organisasi termasuk dalam bentuk perusahaan, pada dasarnya tertuju pada pemenuhan kebutuhan (need) sebagai manusia. Dengan kata lain untuk dapat hidup layak secara manusiawi berdasarkan hakikat kemanusiaannya, manusia memiliki kebutuhan yang harus dipenuhi. Kemampuan untuk memenuhi kebutuhan merupakan persyaratan penting dalam menempatkannya pada kedudukan sesuai dengan harkat dan martabat sebagai manusia (Nawawi, 2017). Oleh karena itu, motivasi kerja dapat diartikan sebagai sesuatu yang dirasakan oleh pegawai yang datang dari dalam diri sendiri. Dengan motivasi kerja yang tinggi, maka kepuasan kerja para pegawai akan meningkat, dan selanjutnya kinerja pegawai pun dapat ditingkatkan. Sedangkan kinerja menurut Simamora (2014) adalah cerminan dari kemampuannya mencapai persyaratan-persyaratan tertentu yang telah ditetapkan atau yang dijadikan standar. Hal ini sejalan dengan pengertian kinerja, yang merupakan hasil kerja para karyawan dalam mencapai kualitas dan kuantitas tertentu sesuai target pekerjaan yang ditetapkan. 
Kantor Badan Pengelola Pajak dan Retribusi Daerah (BPPRD) Kota Palangka Raya adalah salah satu instansi yang mengelola pajak daerah. Lembaga ini sangat berkepentingan dengan kualitas pelayanan, karena berhubungan langsung kepada masyarakat. Karena itu, salah satu yang perlu diperhatikan oleh pemerintah adalah bagaimana meningkatkan kepuasan kerja para pegawai. Upaya selanjutnya adalah memotivasi kerja para pegawai agar bekerja dengan sungguh-sungguh agar kinerja pegawai dapat ditingkatkan. Adapun fenomena yang terjadi pada instansi ini adalah terjadinya penurunan minat masyarakat untuk membayar pajak (komunikasi pribadi dengan Kabid Pelayanan BPPRD Kota Palangka Raya). Hal ini diduga disebabkan penurunan kualitas pelayanan, atau penurunan kepuasan kerja pegawai sehingga kinerja pegawai mereka mennurun, atau disebabkan siklus masa pembayaran belum sesuai jadwalnya. Untuk itu salah satu yang diperlu dievaluasi, selain itu perlu dtinjau kembali pemberian motivasi kerja, agar kepuasan kerja dan kinerja kembali dapat ditingkatkan.

Tabel 1. Data Realisasi Pajak Kota Palangka Raya

\begin{tabular}{ccc}
\hline Tahun & Realisasi (Rp) & Perkembangan \\
\hline 2018 & $80.693 .793 .681,00$ & - \\
2019 & $57.044 .150 .387,84$ & $-29,31 \%$ \\
\hline
\end{tabular}

Sumber: Dinas Pendapatan Daerah

Tabel 1 menunjukan bahwa realisasi pajak yang diterima pemerintah daerah menurun $-29,31 \%$ dari tahun 2018 ke tahun 2019. Hal ini tentu disebabkan oleh berbagai faktor baik dari sisi masyarakat maupun dari sisi organisasinya. Danarsi dan Subroto (2017) mengungkapkan bahwa pemahaman dan kesadaran perpajakan tidak berpengaruh terhadap kepatuhan wajib pajak, sedangkan tarif pajak, kualitas pelayanan dan sanksi perpajakan berpengaruh terhadap kepatuhan wajib pajak. Sementara itu Sulistian (2020) menunjukan bahwa motivasi, dan kesadaran perpajakan berpengaruh positif terhadap kepatuhan wajib pajak. Hal ini menunjukkan bahwa secara internal organisasi para pegawai juga memiliki pengaruh secara personal baik dari sisi pelayanan maupun motivasinya.

Rahayu (2005) mengungkapkan bahwa kualitas pelayanan dan semangat kerja pegawai dapat menyebabkan kepuasan masyarakat. Semangat kerja memiliki pengaruh yang lebih dominan dibandingkan dengan kualitas pelayanan. Murti dan Srimulyani (2013) menunjukan bahwa motivasi berpengaruh signifikan pada kepuasaan kerja, tetapi motivasi tidak berpengaruh signifikan terhadap kinerja pegawai dan kepuasaan kerja berpengaruh signifikan terhadap kinerja pegawai.

Sementara itu Samiun (2016) menyatakan bahwa faktor pribasi, faktor pelayanan dan sosial lah yang menjadi pertimbangan masyarakat wajub pajak. Ghozali (2017) menemukan bahwa motivasi kerja, kepuasan kerja dan kemampuan kerja, berpengaruh terhadap variabel kinerja pegawai. Senada dengan hal tersebut Rahayu (2017) mengungkapkan bahwa motivasi berpengaruh positif terhadap kinerja pegawai.

Berdasarkan uraian diatas, maka diperlukan suatu kajian tentang pengaruh kualitas pelayanan dan motivasi kerja terhadap kinerja melalui kepuasan kerja pegawai Kantor Badan Pengelola Pajak dan Retribusi Daerah Kota Palangka Raya. Tujuan penelitian ini adalah untuk mengukur dan menganalisis pengaruh langsung (direct effect) dan pengaruh tidak langsung (indirect effect) antara kualitas pelayanan, motivasi kerja, terhadap kepuasan kerja dan kinerja serta mengukur dan menganalisis pengaruh langsung (direct effect) dan pengaruh tidak langsung (indirect effect) antara kepuasan kerja terhadap kinerja pegawai Kantor Badan Pengelola Pajak dan Retribusi Daerah Kota Palangka Raya.

\section{METODOLOGI}

Penelitian ini mengukur bagaimana hubungan dan pengaruh sebab-akibat atau disebut juga metode research association, yaitu penelitian yang mencari bentuk hubungan dan pengaruh antara dua variabel atau lebih dalam konsep sebab akibat dari variabel kualitas pelayanan, motivasi kerja, kepuasan kerja dan kinerja. Unit analisis dalam penelitian ini adalah pegawai pada Kantor Badan Pengelola Pajak dan Retribusi Daerah (BPPRD) Kota Palangka Raya.

Menurut Sugiyono (2017), populasi merupakan bagian sektor generalisasi yang terdiri dari subyek yang memiliki kualitas dan sifat tertentu yang ditetapkan peneliti untuk dapat dipelajari yang kemudian dapat ditarik kesimpulannya. Dalam penelitian ini, jumlah masyarakat wajib pajak tidak diketahui populasi, karena semua orang bisa memnjadi wajib pajak. Oleh karena itu akan diambil sampel dari masyarakat wajib pajak ditetapkan sebanyak 100 orang. Dalam 100 orang tersebut hanya dapat diambil dalam kurun waktu 2 bulan. Tenaga pelayanan pada Kantor BPPRD Kota Palangka Raya, sebanyak 106 orang (PNS dan honorer) diambil sebanyak 100 orang. Kantor BPPRD. Masyarakat wajib pajak adalah yang menilai kualitas pelayanan, karyawan/pegawai dapat menilai perasaan terhadap motivasi kerja dan kepuasan kerja. Sedangkan yang menilai kinerja pegawai adalah kasi (kepala seksi) sebagai narasumber, karena mereka lebih tahu dan lebh dengan dengan pegawai.

Data pada penelitian ini yaitu berupa data primer dan data sekunder. Data primer merupakan data yang didapatkan secara langsung oleh peneliti baik hasil pengamatan (observasi) maupun data hasil kuesioner, maupun wawancara kepada pihak masyarakat konsumen, pegawai serta pimpinan. Data primer yaitu data yang didapatkan secara langsung dari sumber asli dan data dikumpulkan untuk menjawab pertanyaan penelitian yang sesuai dengan keinginan peneliti (Mas'ud, 2014). Data 
sekunder merupakan data yang didapatkan untuk menunjang data primer. Data sekunder dikumpulkan atau diolah oleh pihak lain yang sudah berbentuk publikasi, misalnya lembaga pemerintah maupun lembaga atau institusi non-pemerintah yang mempunyai hubungan dengan permasalahan dalam penelitian ini. Mas'ud (2014) menyatakan bahwa data sekunder merupakan data penelitian yang didapatkan oleh peneliti dengan tidak langsung atau melalui perantara (diperoleh dan dicatat oleh pihak lain).

Data dikumpulkan dengan cara observasi dan melalui kuesioner. Teknik observasi (pengamatan), yaitu dengan cara melihat secara langsung gejala-gejala yang ada pada Kantor BPPRD Kota Palangka Raya, terutama kegiatan pelayanan, besarnya kompensasi, perilaku kepuasan kerja dan kinerja. Kuesioner ini untuk melengkapi bahan atau data analisis sehingga dapat diambil kesimpulan, dimana teknik ini digunakan untuk mengetahui kualitas pelayanan dari mata masyarakat konsumen, besarnya kompensasi dari mata pegawai, kepuasan kerja dari mata pimpinan dan kinerja juga dari mata pimpinan.

Analisis dalam peneliti ini menggunakana analisis jalur (path analysis) dimana variabel kualitas pelayanan dan motivasi kerjaadalah vartiabel indepeden (variabel bebas), sedangkan variabel kepuasan kerja adalah variabel perantara (intervening) dan kinerja adalah vartiabel dependen (variabel terikat). Hasil analisis (output) ini digunakan untuk menguji validitas konvergen dari instrumen pengukuran (kuesioner). Validitas konvergen merupakan bagian dari measurement model SEM-PLS yang disebut outler model, sedangkan dalam covariance-based SEM disebut confirmatory factor analysis (CFA).

\section{HASIL}

\subsection{Analisis Deskriptif}

Badan Pengelola Pajak dan Retribusi Daerah (BPPRD) kota Palangka Raya terbentuk pada tahun 2016 berdasarkan Peraturan Daerah (Perda) No. 11 tahun 2016. Sebelumnya Badan ini bernama Dinas Pendapatan Daerah (DISPENDA) yang terbentuk tahun 2011 berdasarkan Peraturan Daerah No. 7 tahun 2011, yang sebelumnya merupakan suatu Bidang Pengelolaan Pendapat Daerah pada Dinas Pengelola Keuangan dan Aset Daerah (DPKAD) berdasarkan Perda No. 12 tahun 2007 tentang Susunan Organisasi dan Tata Kerja Pengelolaan Keuangan dan Aset Daerah.

Badan Pengelola Pajak dan Retribusi Daerah (BPPRD) Kota Palangka Raya secara khusus mempunyai tugas pemungutan sumber-sumber pendapatan pakal dan retribusi daerah serta pengelolaan penerimaan daerah lainnya untuk memenuhi kebutuhan Pemerintah Kota Palangka Raya.

Dari hasil observasi dilapangan pada kantor BPPRD ditemukan bahwa jumlah wanita lebih banyak 54 orang
(54\%) dari pria sebanyak 46 orang (46\%). Ini mungkin ada hubungannya dengan kesabaran, keramahan dan keuletan yang dimiliki wanita dibanding pria yang katanya lebih emosional dalam pelayanan. Secara usia menunjukkan pegawai dengan usai antara 33 tahun sampai 41 tahun sebanyak 44 orang (44\%), kemudian 24 tahun sampai 32 tahun sebanyak 23 orang (23\%), usai 14 tahun sampai 23 tahun sebanyak 14 orang (14\%), usia 42 tahun sampai 50 tahun sebanyak 12 orang (12\%), selanjutnya usia 51 tahun keatas sebanyak 7 orang (7\%).

Masyarakat yang membayar pajak adalah orang-orang wajib pajak kepada Badan Pengelola Pajak dan Retribusi Daerah Kota Palangka Raya. Tampak bahwa masyarakat pembayar pajak pada Badan Pengelola Pajak dan Retribusi Daerah Kota Palangka Raya didominasi oleh pria, yaitu sebanyak 73 orang (73\%) dan wanita sebanyak 27 orang (27\%). Ini karena pria diangap lebih cekatan dan mampu berurusan, dan lebih mobile dalam berurusan.

Dari sisi usia, masyarakat yang membayar pajak pada Badan Pengelola Pajak dan Retribusi Daerah Kota Palangka Raya terbanyak berusia 24 tahun sampai 32 tahun, yaitu sebanyak 37 orang (37\%), kemudian orang yang berusia 33 tahun sampai 41 tahun sebanyak 25 orang (25\%), disusul yang berusia 15 sampai 23 tahun sebanyak 18 orang (18\%), selanjutnya usia 42 tahun sampai 50 tahun sebanyak 11 orang (11\%), dan usia 51 tahun keatas 9 orang (9\%).

Hasil kuesioner menunjukan distribusi dari masingmasing sampel, baik masyarakat wajib pajak yang menilai (mempersepsikan) kualitas pelayanan, pegawai Badan Pengelola Pajak dan Retribusi Daerah Kota Palangka Raya merasakan motivasi kerja dan kepuasan kerja, serta kasi (kepala seksi) yang menilai kinerja pegawai. Secara ratarata kualitas pelayanan yang diberikan oleh pegawai Badan Pengelola Pajak dan Retribusi Daerah Kota Palangka Raya cukup baik, yaitu 3,60, ini karena semuanya diatas nilai (skor) diatas 3 (netral) yang mendekati baik.

Selain itu juga ditemukan bahwa motivasi kerja pegawai pada Badan Pengelola Pajak dan Retribusi Daerah Kota Palangka Raya menunjukan angka (skor) diatas 3 (netral), yaitu 3,54 yang mendekati nilai baik. Kepuasan kerja pegawai pada Badan Pengelola Pajak dan Retribusi Daerah Kota Palangka Raya menunjukan angka (skor) diatas 3 (netral), yaitu 3,34 yang mendekati nilai baik. Kinerja pegawai pada Badan Pengelola Pajak dan Retribusi Daerah Kota Palangka Raya menunjukan angka (skor) diatas 3 (netral), yaitu 3,62 yang mendekati nilai baik.

\subsection{Analisis PLS}

Hasil uji validitas dan reliabilitas (atau pengujian model fit) menunjukan bahwa model tersebut adalah fit, penjelasannya sebagai berikut.

\section{a. Model fit and quality indices}

Average path coefficient $(\mathrm{APC})=0.338, \mathrm{P}<0.001$; Average R-squared (ARS) $=0.596, \mathrm{P}<0.001 ;$ Average adjusted R-squared (AARS) $=0.586, \mathrm{P}<0.001$; Average block VIF $($ AVIF $)=2.009$, acceptable if $<=5$, ideally $<=$ 
3.3; Average full collinearity VIF (AFVIF) $=2.675$, acceptable if $<=5$,ideally $<=3.3$ (Latan dan Ghazali, 2017). Dengan demikian bahwa kriteria goodness of fit model telah memenuhi syarat atau kriteria dimana nilai APC dan ARS harus lebih kecil 0,5 , tetapi $P<0,001$ yang menunjukan signifikan. Atau AVIF sebagai indikator multikoliuritas lebih kecil dari 5. Artinya, evaluasi sesuai atau didukung oleh data, dimana nilai P lebih kecil dari 0,05.

Hasil dari output ini menampilkan konstruk pada kolom dan indikator-indikatornya pada baris. Konstruk kualitas pelayanan diukur dengan indikator 1-4, loading setiap indikator pada konstruknya serta terdapat nilai Pnya. Loading kualitas pelayanan pada konstruk adalah sebesar 0,986 dan siginfikan dengan nilai $P$ kurang dari 0,001 . Demikian juga motivasi kerja dengan loading sebesar 0,985 , dan seterusnya dengan $P<0,001$. Dari nilai loading matrix (unrotated) dan cross-loading dari pattern matrix (rotated) diperoleh nilai kualitas pelayanan 0,986 sampai 0,961, motivasi kerja dari 0,985 sampai 0,970, kepuasan kerja 0,990 sampai 0,985, dan kinerja dari 0,991 sampai 0,312. Dari semua itu hanya kinerja yang tidak signifikan $(0,312)$-nilai signifikansi $P$ value $<0,001$ - maka data tersebut dianalisis lebih lanjut.

\section{b. Cronbach's alpha coefficients}

Hasil uji validitas dan reliabilitas menunjukan cronbach's alpha coefficients diatas 0,60 baik untuk kualitas pelayanan 0,994, motiasi kerja 0,987, kepuasan kerja 0,991 dann kinerja 0,913, yang berarti cukup signifikan. Output ini juga menyajikan dua ukuran reliabilitas instrumen yaitu composite reliability dan cronbach's alpha. Keduanya harus bernilai diatas 0,60 sebagai syarat reliabilitas. Hasil output diatas menunjukan reliabilitas instrumen telah terpenuhi karena diatas 0,60 (Ferdinand, 2014).

\section{c. Average variances extracted}

Average variance extracted (AVE) juga digunakan untuk evaluasi validitas konvergen. Kriteria AVE harus diatas 0,50. Dari hasil output tersebut menujukan kriteria baik untuk kualitas pelayanan sebesar 0,925, motivasi kerja 0,939, kepuasan kerja 0,965 dan kinerja 0,798.

\section{d. Full collinearity VIFs}

Kriteria untuk full collinearty test adalah nilainya harus lebih rendah dari 3,3. Output diatas menunjukan nilai full collinearity VIFs kurang dari 3,3 sehingga model tersebut bebas dari masalah kolinearitas vertikal, lateral, dan common method bias.

\section{e. Q-squared coefficients}

Model dengan validitas prediktif harus mempunyai Qsquared lebih besar dari nol. Hasil dari output hasil estimasi menunjukan validitas prediktif yang baik (yaitu 0,49 dan $0,70)$ karena bernilai diatas atau lebih besar dari nol.

\section{f. Effect sizes for path coefficients}

Hasil dari output estimasi menunjukan effect size pengaruh kualitas pelayanan terhadap kepuasan kerja adalah 0,410 (kuat), dan kualitas pelayanan terhadap kinerja 0,361 (medium), sementara effect size motivasi kerja terhadap kinerja 0,255 (medium) Hasil ini tergolong kelompok effect size kecil sehingga menunjukan kualitas pelayanan dan motivasi kerja mempunyai peran cukup penting dalam meningkatkan kepuasan kerja dan kinerja.

\section{g. Indicator weights}

Bobot indikator (indicator weights) yang merupakan validitas diskriminan konstruk, dimana kesemua varianel baik kualitas pelayanan, motivasi kerja, kepuasan kerja dan kinerja kesemuanya bernilai $P<0,001$ yang menunjukan kesemuanya signifikan dan cukup terpenuhi karena akar AVE, tetapi misalnya kualitas pelayanan sebesar 0,076, sampai untuk ke 13 adalah lebih besar dari $P<0,001$ yaitu $P$ 0,218 sampai $P$ 0,224 yang menunjukan tidak signifikan. Tetapi unsur motivasi kerja sebesar 0,176, kepuasan kerja sebesar 0,205 dan kinerja sebesar 248 kesemuaya signifikan (kecuali unsur le 26 lebih besar dari $P<0,001$ yaitu 0,211 .

\section{h. Correlations among latent variables and errors}

Secara korelasi semuanya signifikan, karena karena $P$ lebih kecil dari 0,001. Hasil analisis uji validitas dan reliabilitas tersebut yang dikatakan signifikan, maka dapat dilanjutkan pada analisis jalur (path analysis).

\subsection{Hasil Analisis Jalur (Path Analysis)}

Dari hasil analisis jalur ini akan diketahui jalur langsung atau pengaruh langsung (direct effect) dan jalur tidak langsung (indirect effect) antara kualitas pelayanan, motivasi kerja, kepuasan kerja dan kinerja.

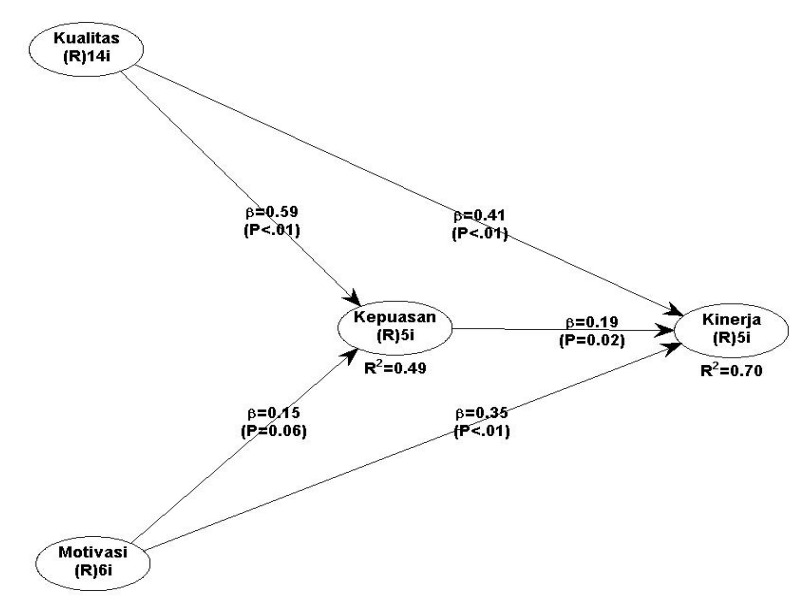

Gambar 1. Analisis Jalur (Path Analysis)

Dari koefisien jalur tersebut hanya motivasi kerja dengan kepuasan kerja yang paling rendah yaitu 0,15 sedangkan kepuasan kerja dengan kinerja 0,19. Dari jalur tersebut diatas dapat dijelaskan bahwa nilai P-values (pengaruh langsung $=$ direct effect) kualitas pelayanan dengan kepuasan kerja, kualitas pelayanan dengan kinerja, motivasi kerja dengan kinerja, serta kepuasan kerja dengan kinerja adalah signifikan karena $\mathrm{P}<0,001$, yang tidak 
signifikan adalah antara motivasi kerja dengan kepuasan kerja yaitu 0,057 karena kebih besar dari 0,05. Total pengaruh memiliki nilai Probability $(P)$-nya adalah masingmasing $P$ lebih kecil dari $0,001(P<0,001)$.

\subsection{Pengaruh Langsung (Direct Effect)}

Hasil penelitian ini menujukan pengaruh langsung (direct effect) antara masing-masing variabel. Hasil analisis menunjukkan bahwa pengaruh kualitas pelayanan terhadap kinerja adalah signifikan, kualitas pelayanan terhadap kepuasan kerja adalah signifikan (0,59 dengan $P$ $<0,001)$, motivasi kerja terhadap kinerja adalah signifikan $(0,35$ dengan $\mathrm{P}<0,001)$, motivasi kerja terhadap kepuasan kerja adalah tidak signifikan $(0,15$ dengan $P>0,05)$, namun kepuasan kerja terhadap kinerja adalah signifikan $(0,41$ dengan $\mathrm{P}<0,001)$.

\subsection{Pengaruh Tidak Langsung (Indirect effect)}

Pengaruh tidak langsung (indirect effect) antara kualitas pelayanan terhadap kinerja melalui kepuasan kerja dan motivasi kerja terhadap kinerja melalui kepuasan kerja. Ternyata kualitas pelayanan terhadap kinerja melalui kepuasan kerja lebih besar $(0,115)$ dari pada motivasi kerja terhadap kinerja melalui kepuasan kerja $(0,030)$. Akan tetapi nilai $R$-squared coefficients-nya (konstribusi atau sumbangan) motivasi kerja terhadap kinerja melalui kepuasan kerja lebih besar $(0,698)$ dibandingkan kontribusi atai sumbangan kualitas pelayanan terhadap kinerja melalui kepuasan kerja hanya sebesar $(0,493)$.

Nilai P-value kualitas pelayanan terhadap kinerja dibawah 0,05, yaitu 0,047, sedangkan motivasi kerja terhadap kinerja lebih besar dari 0,05, yaitu 0,336. Standar penyimpangan pengaruh tidak langsung antara kualitas pelayanan terhadap kinerja adalah 0,068, lebih kecil dari motivasi kerja terhadap kinerja sebesar 0,070. Besarnya pengaruh dari pengaruh tidak langsung (indirect effects) antara kualitas pelayanan terhadap kinerja melalui kepuasan kerja adalah sebesar 0,090 sedangkan motivasi kerja terhadap kinerja melalui kepuasan kerja adalah sebesar 0,022.

Nilai jumlah (total) pengaruh tidak langsung (indirect effects) antara kualitas perlayanan terhadap kinerja melalui kepuasan kerja adalah sebesar 0,115 , sedangkan motivasi kerja terhadap kinerja melalui kepuasan kerja adalah sebesar 0,030 . Nilai $\mathrm{P}$-value kualitas pelayanan terhadap kinerja masih dibawah 0,05, yaitu 0,047 sedangkan motivasi kerja terhadap kinerja lebih besar dari 0,05, yaitu 0,336 . Standar penyimpangan pengaruh tidak langsung antara kualitas pelayanan terhadap kinerja adalah 0,068, lebih kecil dari nilai motivasi kerja terhadap kinerja sebesar 0,070 .

Besarnya pengaruh dari pengaruh tidak langsung (indirect effects) antara kualitas pelayanan terhadap kinerja melalui kepuasan kerja adalah sebesar 0,090; sedangkan motivasi kerja terhadap kinerja melalui kepuasan kerja adalah sebesar 0,022. Penyimpangan standar untuk total pengaruh, dimana masing-masing variabel antara kualitas pelayanan terhadap kepuasan kerja adalah 0,085, kualitas pelayanan terhadap kinerja adalah 0,086 , motivasi kerja terhadap kepuasan kerja adalah 0,095, motivasi kerja terhadap kinerja adalah 0,090, dan kepuasan kerja terhadap kinerja adalah 0,094.

Besarnya pengaruh untuk total pengaruh, dimana kualitas pelayanan terhadap kepuasan kerja adalah 0,410 dan kinerja adalah 0,406 . Motivasi kerja terhadap kepuasan kerja adalah 0,083 dan kinerja adalah 0,276, sedangkan kepuasan kerja terhadap kinerja adalah 0,128. Sumbangan (konstribusi) antara kualitas pelayanan terhadap kepuasan kerja adalah 0,410 dan terhadap kinerja adalah 0,316, motivasi kerja terhadap kepuasan kerja adalah 0.083 dan terhadap kinerja adalah 0,255, dan kepuasan kerja terhadap kinerja adalah 0,128.

Dari hasil analisis jalur (path analysis) dimana pengaruh langsung (direct effect) antara kualitas pelayanan terhadap kepuasan kerja maupun terhadap kinerja signifikan, dan motivasi kerja terhadap kepuasan kerja tidak signifikan, tetapi terhadap kinerja signifikan. Sedangkan pengaruh tidak langsung (indirect effects) kualitas pelayanan terhadap kinerja melalui kepuasan kerja dengan koefisien 0,115 lebih besar dari motivasi kerja terhadap kinerja melalui kepuasan kerja sebesar 0,030.

Nilai P-value kualitas pelayanan terhadap kinerja masih dibawah 0,05, yaitu 0,047 sedangkan motivasi kerja terhadap kinerja lebih besar dari 0,05, yaitu 0,336. Standar penyimpangan pengaruh tidak langsung antara kualitas pelayanan terhadap kinerja adalah 0,068, lebih kecil dari nilai motivasi kerja terhadap kinerja lebih besar yaitu 0,070. Penyimpangan standar total pengaruh, masing-masing variabel antara kualitas pelayanan terhadap kepuasan kerja adalah 0,085 , kualitas pelayanan terhadap kinerja adalah 0,086, motivasi kerja terhadap kepuasan kerja adalah 0,095, motivasi kerja terhadap kinerja adalah 0,090, dan kepuasan kerja terhadap kinerja adalah 0,094.

Total pengaruh kualitas pelayanan terhadap kepuasan kerja adalah 0,410 dan kinerja adalah 0,406. Pengaruh motivasi kerja terhadap kepuasan kerja adalah 0,083 dan kinerja adalah 0,276, sedangkan kepuasan kerja terhadap kinerja adalah 0,128. Kontribusi (sumbangan) distribusi kualitas pelayanan terhadap kepuasan kerja adalah 0,410 dan terhadap kinerja adalah 0,316, motivasi kerja terhadap kepuasan kerja adalah 0.083 dan terhadap kinerja adalah 0,255, dan kepuasan kerja terhadap kinerja adalah 0,128.

\section{PEMBAHASAN}

Diantara hubungan atau pengaruh tersebut adalah hubungan atau pengaruh motivasi kerja dengan kepuasan kerja yang tidak siginifikan. Hal ini terjadi karena motivasi kerja adalah dorongan yang datang dari dalam diri sendiri untuk lebih berkinerja. Karena itu motivasi kerja langsung ke kinerja tanpa melalui kepuasan kerja akibatnya motivasi kerja tidak signifikan melalui kepuasan kerja.

Kualitas pelayanan terhadap kinerja melalui kepuasan kerja (pengaruh tidak langsung) lebih besar dari pengaruh 
langsung kualitas pelayanan terhadap kinerja. Hal ini dipengaruhi oleh terciptanya kualitas pelayanan yang dirasakan oleh masyarakat wajib pajak adalah hasil karya pegawai yang mendapatkan kepuasan kerja, karena jika pegawai merasakan kepuasan kerja maka ia akan memberikan pelayanan yang terbaik dengan senang hati. Variabel kepuasan kerja adalah variabel perantara yang memperkuat pengaruh kualitas pelayanan tergadap kinerja. Hal ini sejalan dengan penelitian Rahayu (2005) yang menyatakan bahwa kualitas pelayanan berpengaruh terhadap kinerja dan kepuasan masyarakat. Jadi, dengan kepuasan kerja pegawai maka ia mampu memberikan kualitas pelayanan bagi masyarakat wajib pajak.

Sementara itu, pengaruh langsung motivasi kerja terhadap kinerja berpengaruh signifikan. Hal ini sejalan dengan penelitian yang dilakukan oleh Ghozali (2017), Rahayu (2017), Prayitno et al. (2020) yang menyatakan bahwa motivasi berpengaruh signifikan terhadap kinerja pegawai. Pendapat berbeda dikemukakan oleh Murti dan Srimulyani (2013) yang menyatakan bahwa motivasi tidak berpengaruh signifikan terhadap kinerja, tetapi hanya pada kepuasan kerja.

Sedangkan pengaruhi tidak langsung (motivasi kerja terhadap kinerja melalui kepuasan kerja) tidak signifikan. Ini karena motivasi kerja adalah daya dorong dari dalam diri sendiri para pegawai untuk berkinerja yang lebih baik lagi, akibatnya motivasi kerja tidak melalui kepuasan kerja, sehingga tidak signifikan. Disisi lain dengan adanya motivasi kerja akan memunculkan daya dorong dari dalam diri sendiri. Hal ini akan berpengaruh terhadap kinerja, tanpa melalui kepuasan kerja. Oleh karena itu dua hal yang perlu diperhatikan pihak manajemen yaitu kepuasan kerja pegawai dan motivasi kerja pegawai.

Kuatnya motivasi kerja terhadap kinerja tanpa melalui kepuasan kerja mempunyai besaran 0,698, artinya kuatnya motivasi kerja terhadap kinerja sebesar 0,698. Akan tetapi jika melalui kepusan kerja maka motivasi kerja melalui kepusan kerja menjadi tidak sifnifikan. Sedangkan standar penyimpangan pengaruh tidak langsung antara kualitas pelayanan terhadap kinerja adalah 0,068 lebih kecil dari motivasi kerja terhadap kinerja lebih besar yaitu 0,070. Ini menujukan bahwa kuatnya motivasi kerja terhadap kinerja adalah karena adanya daya dorong dari dalam diri sendiri untuk meningkatkan kinerja.

Dari hasil analisis jalur (path analysis) dimana pengaruh langsung (direct effect) antara kualitas pelayanan terhadap kepuasan kerja maupun terhadap kinerja signifikan, dan motivasi kerja terhadap kepuasan kerja tidak signifikan. Ketidaksignifikan antara motivasi kerja terhadap kinerja melalui kepuasan kerja, karena motibasi kerja adalah daya dorong yang datang dari dalam diri senditi untuk berkinerja, sehingga mengabaikan kepuasan kerja, ini terbukti bahwa motivasi kerja terhadap kinerja signifikan. Sedangkan pengaruh tidak langsung (indirect effects) kualitas pelayanan terhadap kinerja melalui kepuasan kerja dengan koefisien 0,115 lebih besar dari motivasi kerja terhadap kinerja melalui kepuasan kerja sebesar 0,030.

\section{KESIMPULAN}

Berdasarkan hasil analisis penelitian dapat ditarik kesimpulan yang menunjukkan bahwa terdapat pengaruh langsung (direct effect) antara kualitas pelayanan terhadap kinerja adalah signifikan, kualitas pelayanan terhadap kepuasan kerja adalah signifikan (0,59 dengan $P<0,001)$, motivasi kerja terhadap kinerja adalah signifikan $(0,35$ dengan $\mathrm{P}<0,001)$, motivasi kerja terhadap kepuasan kerja adalah tidak signifikan $(0,15$ dengan $P>0,05)$, namun kepuasan kerja terhadap kinerja adalah signifikan $(0,41$ dengan $\mathrm{P}<0,001)$.

Dari hasil analisis jalur (path analysis) dimana pengaruh langsung (direct effect) antara kualitas pelayanan terhadap kepuasan kerja maupun terhadap kinerja berpengaruh signifikan, dan motivasi kerja terhadap kepuasan kerja tidak signifikan. Sedangkan pengaruh tidak langsung (indirect effects) kualitas pelayanan terhadap kinerja melalui kepuasan kerja dengan koefisien 0,115 lebih besar dari motivasi kerja terhadap kinerja melalui kepuasan kerja sebesar 0,030, artinya motivasi kerja terhadap kinerja melalui kepuasan kerja memiliki pengaruh yang tidak signifikan.

\section{DAFTAR PUSTAKA}

Danarsi, S. N., \& Subroto, H., 2017. Faktor-Faktor Yang Mempengaruhi Kepatuhan Wajib Pajak dalam Membayar Pajak Mobil dengan Diberlakukannya Pajak Progresif di Kota Surakarta. Jurnal Akuntansi dan Pajak, 18(1), 45-55.

Ferdinand, A., 2014. Structural Equation Modeling dalam Penelitian Manajemen. Semarang: Penerbit BP UNDIP.

Ghozali, I., 2017. Pengaruh Motivasi Kerja, Kepuasan Kerja dan Kemampuan Kerja Terhadap Kinerja Pegawai Pada Kantor Kementerian Agama Kabupaten Banjar. Jurnal Ilmiah Ekonomi Bisnis, 3(1), 130-137.

Hasibuan, M., 2016. Manajemen Sumber Daya Manusia. Edisi Revisi. Jakarta: Bumi Aksara.

Kotler, P., 2018. Manajemen Pemasaran: Analisis, Perencanaan, Implementasi, dan Pengendalian. Jakarta: PT. Prenhallindo.

Latan, \& Ghazali, I., 2012. Structural Equation Modelling (SEM) metode alternative dengan Partial Least Square. Semarang: BP. Universitas Diponegoro

Mas'ud, F., 2014. Survey Diagnosis Organisasional (Konsep dan Aplikasi). Semarang: BP-Universitas Diponegoro.

Murti, H., \& Srimulyani, V. A., 2013. Pengaruh Motivasi Terhadap Kinerja Pegawai dengan Variabel Pemediasi Kepuasaan Kerja Pada PDAM Kota Madiun. JRMA| Jurnal Riset Manajemen dan Akuntansi, 1(1), 10-17.

Nawawi, H., 2017. Manajemen Sumber Daya Manusia untuk Bisnis dan Kompetitif. Cetakan Keempat. Yogyakarta: Penerbit Gadjah Mada University Press.

Prayitno, J.H., Mawung, A.S. and Syamsudin, A., 2020. Pengaruh Kompetensi, Insentif dan Motivasi terhadap 
Kinerja Pegawai pada Badan Narkotika Nasional Provinsi Kalimantan Tengah. Journal of Environment and Management, 1(2), 91-102.

Rahayu, A., 2005. Pengaruh Kualitas Pelayanan dan Semangat Kerja Pegawai Terhadap Kepuasan Masyarakat Yang Dilayani Pada Kantor Kecamatan Rembang Kabupaten Rembang. Tesis. Semarang: UNS.

Rahayu, K. W., 2017. Pengaruh Motivasi Kerja Terhadap Kinerja Pegawai Pada Sekretariat Daerah Kabupaten Kutai Timur. Ekonomia, 6(1), 177-182.

Robbins, S. P., 2016. Prinsip-prinsip Perilaku Organisasi. Jakarta: Penerbit Erlangga.

Samiun, 2016. Faktor-Faktor Yang Menjadi Pertimbangan Wajib Pajak Untuk Membayar Pajak Bumi Dan Bangunan Dikecamatan Praya Barat Daya Kabupaten Lombok Tengah (Studi Kasus Pada Desa Pelambik Dan Desa Kabul). Jurnal Sangkareang Mataram, 2(3), 88-116.
Simamora, H., 2014. Manajemen Sumber Daya Manusia. Yogyakarta: STIE YKPN.

Sugiyono, 2017. Metode Penelitian Bisnis. Bandung: Penerbit Alfabeta.

Sulistian, D., 2020. Pengaruh Faktor Motivasi, Pengetahuan Perpajakan, dan Kesadaran Perpajakan Terhadap Kepatuhan Wajib Pajak (Studi Empiris pada Wajib Pajak Orang Pribadi yang terdaftar di KPP Pratama Jakarta Palmerah). Doctoral dissertation. Jakarta: Universitas Mercu Buana.

Undang-Undang Republik Indonesia Nomor 25 Tahun 2004 Tentang Sistem Perencanaan Pembangunan Nasional dengan Rahmat Tuhan Yang Maha Esa Presiden Republik Indonesia. (5 Oktober 2004) Lembaran Negara Republik Indonesia Tahun 2004 Nomor 104. Jakarta. 